\title{
EFFECT OF DIETARY HUMATE SUPPLEMENTATION ON GROWTH PERFORMANCE, CARCASS TRAITS AND INTESTINAL MICROFLORA IN LOCAL CHICKS
}

\author{
R. A. Hassan ${ }^{1}$, W. A. Morsy ${ }^{1}$, Nadia L. Radwan ${ }^{1}$ and Y. Eid ${ }^{2}$ \\ 1- Animal Production Research Institute, Agricultural Research Center, Ministry \\ of Agriculture, Dokki, Cairo, Egypt, 2- Department of Poultry Production, Faculty \\ Of Agriculture, Kafrelsheikh University
}

\section{SUMMARY}

The current study was carried out to determine the influence of dietary supplemented humate including humic, fulvic and ulmic acids and some microminerals on local chicks performance, carcass traits and intestinal microflora of local chicks. A study was conducted with total 400 one day-old unsexed local chicks (El-Salam Strain). Chicks were allocated to four dietary treatments $\left(H_{0}, H_{l}\right.$, $\mathrm{H}_{2}$ and $\mathrm{H}_{3}$ groups) as completely randomized experimental design. Feed and water offered ad libitum throughout experimental period (12 wks). A basal diet $\left(H_{0}\right)$, basal diet plus $0.10\left(\mathrm{H}_{1}\right), 0.25\left(\mathrm{H}_{2}\right)$ and $0.40 \%\left(\mathrm{H}_{3}\right)$ humate (BioFarm DRY, Humate, Farmavet International Inc., Kocaeli 41400, Turkey) were fed during experimental period. At the end of the trial (12 wk), 20 birds were slaughtered for measuring carcass traits. Feed intake and body weight were weekly recorded.

The results showed that body weight, feed conversion ratio and carcass traits were positively influenced by humates supplementation (0.25\%) during the experimental period. Diets supplemented with humate $(0.25 \%)$ enhanced the digestibility coefficients of most nutrients compared to the control. Feeding dietary humates led to detrimental reduction in ileal content of coliforms bacteria and bacterial total count, but the population of lactobacilli bacteria was slightly increased. Ileal pH values were slightly increased as dietary humate increased. Gradually. Blood content of total proteins were significantly decreased, while there was no significant effect on blood total lipids or cholesterol concentrations were found.

The results suggested that humate supplementation in diet of growing local chicks may improve the growth rate as a result of the modification effect of humates on microbial populations of lumen.

Keywords: Humate, Growth performance, Carcass traits, Iintestinal microfora, Local chicks

\section{INTRODUCTION}

Feed is the major item of cost in the production of poultry meat and eggs. In addition to feedstuffs, some microbiological cultures and various chemical agents such as probiotics, prebiotics, humates and enzymes, etc. have been adding to animal diets as feed additive to enhance nutrient utilization, improve feed conversion

Issued by The Egyptian Society of Animal Production 
efficiency and maintain health status. But during the past years, inclusion of probiotics and humates in rations is preferable to antibiotics, primarily because they cause no harmful effects on consumers (Yoruk et al., 2004).

Organic matter in the soil exists in three different forms: (1) Living plant and animal matter, (2) Dead plant and animal matter and (3) Decomposed plant and animal matter (humic substances). So humic substances are the most common forms of organic carbon in the natural environment.

Humates, a part of fertilizers, are derived from plant matter decomposed by bacteria (Seen and Kingman, 1973) and contain humus, humic acid, fulvic acid, ulmic acid and some microelements (Stevenson, 1994). Previous studies related to humates have focused mainly on the growth of germinal tissue in seeds. The idea of using humates as feed additives in animal nutrition is new. Firstly humates were used as a part of replacement the rapy for digestive system disturbances such as malnutrition, diarrhea and for feed conversion efficiency (in calves, dogs and cats). Remarkable changes in electrolyte balance and enhancements in immune potency of poultry (Yoruk et al., 2004 and Parks et al., 1986) in response to humate supplementation have been reported. In addition, consistent agreements in the limited numbers of published articles show that humates promote growth by altering partitioning of nutrient metabolism (Parks, 1998), reducing mortality (Eren et al., 2000) and improving feed conversion efficiency (Yoruk et al., 2004 and Eren et al., 2000).

The objective of the present study was to investigate the effect of humate supplementation on growth performance, carcass traits and intestinal microflora of local chicks.

\section{MATERIALS AND METHODS}

This work was carried out at Sakha Animal Production Research Station, Animal Production Research Institute, Agricultural Research Center.

\section{Birds and Experimental Design:}

A total number of 400 day-old unsexed chicks of El-Salam strain [Nicolas X Mamourah (Alexandria X Dokki4)] were used. All birds were wing banded, individually weighted and distributed into four equal experimental treatments. Each treatment was replicated five times with 20 chicks per replicate. The average initial live body weights of all replicates were nearly similar. The experimental treatments were as follows:

(1) $\mathrm{H}_{0}$ was fed the basal diet only (control).

(2) $\mathrm{H}_{1}$ was fed the basal diet plus $0.1 \%$ humate.

(3) $\mathrm{H}_{2}$ was fed the basal diet plus $0.25 \%$ humate.

(4) $\mathrm{H}_{3}$ was fed the basal diet plus $0.40 \%$ humate.

Each $\mathrm{kg}$ of humate contained $160 \mathrm{mg}$ polymeric polyhydroxy acid (Humic, Fulvic, Ulmic and Humatomelanic acids), $663.3 \mathrm{Sio}_{2}$ and other minerals (Mn, $50 \mathrm{mg}$; $\mathrm{Zn}, 60 \mathrm{mg}$; Fe, 60mg; Cu, $5 \mathrm{mg}$; Co, $0.2 \mathrm{mg}$; I, $1 \mathrm{mg}$; Se, $0.5 \mathrm{mg}$ and Al, Na, K, Mg and $\mathrm{P}$ in trace amounts).

\section{Management and Feeding:}

All experimental birds were reared in 20 floor pens $(1 \mathrm{X} 1 \mathrm{~m})$ furnished with rice hulls under the same environmental conditions and continuous lighting. Water and 
feed were provided ad libitum throughout the experimental period. The chicks were vaccinated against the common poultry diseases according to the conventional program used for layer chicks. Basal diets were formulated to cover nutrient requirements (Table 1) according to Egyptian Feed Composition Table (2001).

Table 1. Composition and calculated analysis of the experimental diets

\begin{tabular}{lcc}
\hline \multicolumn{1}{c}{ Ingredients \% } & \multicolumn{1}{c}{ Diets } \\
\cline { 2 - 3 } & Starter ( 0-8 wk) & Grower ( 8-12 wk) \\
\hline Yellow corn & 64.00 & 63.00 \\
Soybean meal (44\% CP) & 32.10 & 17.60 \\
Wheat bran & 00.00 & 15.68 \\
Di-calcium phosphate & 1.80 & 1.25 \\
Limestone & 1.40 & 1.80 \\
Sodium chloride & 0.30 & 0.30 \\
Vit. min. mixture (premix) & 0.30 & 0.30 \\
Dl-Methionine & 0.10 & 0.07 \\
Total & $\mathbf{1 0 0}$ & $\mathbf{1 0 0}$ \\
Calculated analysis & & 2707 \\
ME (kcal/ kg) & 2860 & 15.56 \\
CP (\%) & 19.56 & 3.01 \\
Crude fat ( \% ) & 2.69 & 4.34 \\
Crude fiber ( \% ) & 3.65 & 0.97 \\
Calcium ( \% ) & 1.03 & 0.39 \\
Available Phosphorus (\%) & 0.47 & 0.33 \\
Methionine (\%) & 0.41 & 0.54 \\
Methionine and cystine ( \%) & 0.74 & 0.73 \\
Lysine (\%) & 1.03 & \\
\hline Suplied per kg of diet : Vit. A, 10.000 IU; Vit. D3, 2000IU; Vit. E, 10 mg ; Vit. K3, 1 mg; \\
Vit. B1, 1 mg; Vit. B2, 5 mg; Vit. B6, 1.5 mg ; Vit. B12, 10 mcg; Niacin, 30 mg; Pantothenic \\
acid, 10 mg ; Folic acid , 1 mg; Biotin, 50 mcg ; Choline, 260 mg ; Copper, 4 mg; Iron, 30 \\
mg; Manganese, 60 mg; Zinc, 50 mg; Iodine, 1.3 mg; Selenium, 0.1 mg ; Cobalt, 0.1 mg . \\
\end{tabular}

\section{Productive Traits:}

Individual live body weights and feed intake were recoded at 4, 8 and 12 weeks of age, while body weight gain and feed conversion were calculated during the same experimental periods. Mortality was daily recorded and taken into consideration to adjust feed intake data on a chick-day basis.

\section{Nutrient Digestibility:}

At the end of the experiment (12 wks of age), 5 birds from each group were housed in separate metabolic cages for 5 days. Birds were allowed to the experimental diets for 2 days as preliminary period followed by 3 days as a main experimental period. Feed intake was recorded and excreta were collected during this period. The proximate analyses of feed and dried excreta were carried out according to AOAC (2000). Fecal protein was determined using the method of Jakobsen et al. (1960).

\section{Blood Samples and Analysis:}


Blood samples were collected during the slaughter test in heprinized tubes. Plasma was separated by centrifugation for 15 minutes (3000 rpm / min) and stored in vials at $-20^{\circ} \mathrm{C}$ for later analysis. Part of blood samples was used for hematological analysis including determination of haemoglobin concentration was determined in fresh blood samples using haemoglobinometer as the method described by Pilaski (1972). Red blood cells (RBC's) and white blood cells (WBC's) were counted in fresh blood sample as the method described by Howkey and Dennett (1989). Another part of blood was centrifuged at $3000 \mathrm{rpm}$ for $10 \mathrm{~min}$. to separate plasma. Plasma samples were stored at $-20^{\circ} \mathrm{C}$ until used for determination of total protein (Doumas, 1971), albumin (Witt and Trendelenbug, 1982). Globulin concentration was calculated as the difference between total protein and albumin. Assay of plasma aspartate amino transaminase (AST) and alanine amino transaminase (ALT) enzymes activities were conducted according to Reitman and Frankel (1957). Plasma total lipids (TL) and total cholesterol (Chol) were determined according to Zollner and Kirsch (1962) and Stein (1986), respectively. In this respect, Ca, inorganic phosphorus and iron were determined by specific diagnaostic kits (Bio Merieux, France) according to guidelines and recommendation of Bogin and Kellar (1987).

\section{Carcass traits:}

At the end of experimental period (12 wks), five birds near the average live body weight of each treatment were chosen and sacrificed for slaughter test. The assigned birds were deprived of feed for 16 hours, they were then individually weighed, slaughtered to complete bleeding. Organ weights were expressed as percentages of body weight. A total number of 20 samples from meat (as mixture of $50 \%$ breast + $50 \%$ thigh), The chemical compositions of muscles were determined (AOAC, 2000).

\section{Response to SRBC's:}

At the end of the $8^{\text {th }}$ week of age, ten birds from each treatment were used to determine the humoral immune response (primary responses) by injection intravenously with $1 \mathrm{ml}$ sheep red blood cell (SRBC's) 7\% suspension in sterile saline. To determine secondary response the same antigen was injected 3 weeks later to the same birds. Seven day later, (Yamamoto and Glick, 1982) approximately, 2.0 $\mathrm{ml}$ of blood was drown from each bird. It was allowed to clot to provide serum for antibody titration. Sera were frozen for the later use. The sera samples were inactivated by incubation at $56 \mathrm{c}$ for 30 minutes before titration. The immune responses (primary and secondary) to SRBC's were determined using micro titer technique as described by Kai et al. (1988).

\section{pH Values:}

$\mathrm{pH}$ values of ileal content were determined by mixing one gram of ileal sample with $9 \mathrm{ml}$ of distilled water . $\mathrm{pH}$ meter was used in the determination of $\mathrm{pH}$ values.

\section{Microbiological Study:}

Bacterial total count, coliforms count and lactobacilli bacteria were carried out according to American Public Health Association, A.P.H.A. (1985).

\section{Economic Efficiency:}

The economics of production including feed and humate costs, income and returns per bird were calculated, while the other productive factors were disregarded 
since they were constant. Economic efficiency (EE) is defined as the net revenue per unit feed cost, which was calculated from input-output analysis.

\section{Statistical Analysis:}

The obtained data were statistically analyzed using one way ANOVA (SAS, 1998). Before analysis, all percentages were subjected to logarithmic or arcsine values transformation $(\log 10 x+1)$ to approximate normal distribution. Significant differences among treatment means $(\mathrm{p} \leq 0.05)$ were separated by Duncan's new multiple range test (Duncan, 1955).

The following model was used to study the effect of humate levels on parameters investigated as follows:

Where

$$
\mathrm{Yij}=\mu+\mathrm{Ti}+\mathrm{eij}
$$

$$
\begin{aligned}
& \text { Yij }=\text { an observation } \\
& \mu=\text { Overall mean } \\
& \mathrm{Ti}=\text { Treatments }(\mathrm{i}=1,2 \ldots \text { and } 4) \\
& \text { eij= residual " random error }
\end{aligned}
$$

\section{RESULTS AND DISCUSSION}

\section{Growth Performance:}

The effect of humate on live body weight, body weight gain, feed consumption and feed conversion ratio is presented in Table 2. It is apparent that the differences between control $\left(\mathrm{H}_{0}\right)$ and treatment groups in terms of live body weight and body weight gain $\left(\mathrm{H}_{1}, \mathrm{H}_{2}\right.$ and $\left.\mathrm{H}_{3}\right)$ were not significant at the 4 wks of age. The live body weight and body weight gain were significantly higher in $\mathrm{H}_{2}$ group than that of $\mathrm{H}_{0}$, $\mathrm{H}_{1}$ and $\mathrm{H}_{3}$ groups at 8 and 12 weeks of age. At the end of the experiment (12 week of age), live body weight differed significantly $(\mathrm{P}<0.05)$ in the 4 treatments. The highest mean live body weight was recorded in $0.25 \%$ humate group $(1146.8 \mathrm{~g})$, followed by $0.1 \%$ humate group (1107.5 g), 0.40\% humate group (1093.5 g) and control group $(1084.2 \mathrm{~g})$ respectively . The mean live body weight of birds fed diets containing 0.1 and $0.4 \%$ humate were lower than those of the birds on the diet containing $0.25 \%$ humate $(\mathrm{P}<0.05)$. The addition of $0.25 \%$ humate to the diets increased live body weight and body weight gain by approximately $5.8 \%$ and $5.9 \%$, respectively as compared to the control group.

The cumulative feed consumption value of chicks fed dietary humate did not significantly $(\mathrm{P}<0.05)$ differ from the control. Feed conversion ratio significantly differed from $0-12$ weeks of age. Addition of $0.25 \%$ humate to the diets improved feed conversion ratio by approximately $7.4 \%$ compared to the control group. Mortality rate for chicks fed the control diet was not different from those fed humate levels diets.

Recently, it has been observed that humate inclusion in feed and water of poultry promotes growth (Eren et al., 2000). Kocabagli et al. (2002) used (2.5 g/kg) of Farmagulator DRY TM Humate (FH) (Farmavet International) during different feeding periods (control - without FH), FH from 0 - 21 days (starter period), FH from 22-42 days (grower period). They concluded that feeding FH during the grower period had the most beneficial effect in terms of growth and feed conversion. Also, 
(Eren et al., 2000), compared the effects of dietary humates (Farmagulator DRY ${ }^{\mathrm{TM}}$ ) supplementation at 1.5 and $2.5 \mathrm{~g} / \mathrm{kg}$ feed on broiler performance from 0 to $42 \mathrm{~d}$. Although there was no performance difference at $21 \mathrm{~d}$, yet dietary supplementation of humate at $2.5 \mathrm{~g} / \mathrm{kg}$ significantly improved the live weights of broilers at 42 days of age.

Table 2. Growth performance in local chicks as affected by humates supplementation

\begin{tabular}{|c|c|c|c|c|c|c|}
\hline \multirow{2}{*}{$\begin{array}{c}\text { Age } \\
\text { (weeks) }\end{array}$} & \multicolumn{4}{|c|}{ Humate levels (\%) } & \multirow{2}{*}{ SEM } & \multirow{2}{*}{ P-value } \\
\hline & $\mathbf{0}$ & 0.1 & 0.25 & 0.40 & & \\
\hline \multicolumn{7}{|c|}{ Live body weight (g) } \\
\hline $\mathbf{0}$ & 30.53 & 30.80 & 30.50 & 30.20 & 0.103 & 0.242 \\
\hline 4 & 290.20 & 296.13 & 291.83 & 287.53 & 1.714 & 0.386 \\
\hline 8 & $706.87^{\mathrm{b}}$ & $721.47^{\mathrm{b}}$ & $742.83^{\mathrm{a}}$ & $709.86^{\mathrm{b}}$ & 5.072 & 0.016 \\
\hline 12 & $1084.20^{\mathrm{b}}$ & $1107.46^{\mathrm{b}}$ & $1146.83^{\mathrm{a}}$ & $1093.5^{\mathrm{b}}$ & 8.202 & 0.006 \\
\hline \multicolumn{7}{|c|}{ Body weight gain (g) } \\
\hline $0-4$ & 259.67 & 265.33 & 261.33 & 257.33 & 2.387 & 0.744 \\
\hline 4-8 & $416.67^{b}$ & $425.34^{\mathrm{b}}$ & $451.00^{\mathrm{a}}$ & $422.33^{\mathrm{b}}$ & 4.564 & 0.009 \\
\hline $8-12$ & $377.33^{\mathrm{b}}$ & $385.99^{b}$ & $404.00^{\mathrm{a}}$ & $383.64^{\mathrm{b}}$ & 3.721 & 0.033 \\
\hline $0-12$ & $1053.67^{\mathrm{c}}$ & $1076.66^{\mathrm{b}}$ & $1116.33^{\mathrm{a}}$ & $1063.30^{\mathrm{bc}}$ & 7.722 & 0.001 \\
\hline \multicolumn{7}{|c|}{ Feed consumption (g/ bird/ 28 day) } \\
\hline $0-4$ & 766.66 & 760.00 & 770.00 & 761.66 & 3.526 & 0.792 \\
\hline 4-8 & 955.33 & 946.66 & 914.00 & 958.33 & 7.697 & 0.141 \\
\hline $8-12$ & 990.66 & 981.66 & 980.66 & 980.00 & 3.045 & 0.634 \\
\hline 0-12 & 2712.66 & 2688.33 & 2664.66 & 2700.00 & 10.329 & 0.454 \\
\hline \multicolumn{7}{|c|}{ Feed conversion ( $\mathrm{g}$ feed/ $\mathrm{g}$ body weight gain) } \\
\hline $0-4$ & 2.95 & 2.86 & 2.94 & 2.96 & 0.025 & 0.456 \\
\hline $4-8$ & $2.29^{\mathrm{a}}$ & $2.22^{\mathrm{a}}$ & $2.02^{\mathrm{b}}$ & $2.27^{\mathrm{a}}$ & 0.038 & 0.006 \\
\hline $8-12$ & 2.62 & 2.54 & 2.42 & 2.55 & 0.030 & 0.111 \\
\hline $0-12$ & $2.57^{\mathrm{a}}$ & $2.49^{\mathrm{a}}$ & $2.38^{\mathrm{b}}$ & $2.53^{\mathrm{a}}$ & 0.026 & 0.012 \\
\hline
\end{tabular}

Yasar et al. (2002) concluded that humic acid (HA) caused an increase in weight gain of rats. The improved weight gain was associated with increased ileal epithelial mass, increased feed intake, improved feed: gain ratio and increased nitrogen retention in rats. Simultaneously, as a result of a higher food conversion rate and enhanced absorption of nitrogen by the animal, nitrogenous wastes and odour were reduced. It was also concluded by Ceylan and Ciftci (2002) that HA could be used as be an alternative to antibiotic growth promoters in broiler diets.

These results agreed with Islam et al. (2005) who indicated that replacing antibiotic with humic acid as growth promoter in animal feed does not cause any loss in the performance of animals. They also added that HA has many beneficial effects like anti-bacterial, anti-viral and anti-inflammatory in animals that improves immune system, stress management and reduce odour in faeces. Humic acid has positive effect on liver functions. The improvement in weight gain and FCR by supplemental 
humate could be related to their promoting effects on metabolic processes of digestion and utilization of nutrients (Yeo and Kim, 1997).

\section{Carcass traits:}

Some carcass characteristics of chicks fed different treatments are presented in Table 3. Humate addition at 0.1 and $0.25 \%$ insignificantly improved dressing percentages by 1.74 and $2.10 \%$, respectively compared to control. No significant differences between chicks fed diet containing $0.40 \%$ and control in the term of dressing percentage were noticed. Increasing the levels of humate had no significant effect on abdominal fat. The results were supported by Karaoglu et al. (2004) who reported that humate supplementation to diets of broilers had no significant effect on slaughter and carcass characteristics.

Table 3. Some carcass characteristics in local chicks as affected by humates supplementation

\begin{tabular}{|c|c|c|c|c|c|c|}
\hline \multirow{2}{*}{ Item } & \multicolumn{4}{|c|}{ Humate levels (\%) } & \multirow{2}{*}{ SEM } & \multirow{2}{*}{ P-value } \\
\hline & $\mathbf{0}$ & 0.1 & 0.25 & 0.40 & & \\
\hline \multicolumn{7}{|c|}{ Carcass characteristics (\%) } \\
\hline Dressing & 65.36 & 66.50 & 66.73 & 65.56 & 0.335 & 0.432 \\
\hline Abdominal Fat & 0.223 & 0.216 & 0.217 & 0.223 & 0.004 & 0.948 \\
\hline Liver & $2.30^{\mathrm{b}}$ & $2.36^{\mathrm{b}}$ & $2.80^{\mathrm{a}}$ & $2.50^{\mathrm{b}}$ & 0.057 & 0.082 \\
\hline Bursa & 0.250 & 0.246 & 0.246 & 0.240 & 0.003 & 0.842 \\
\hline Spleen & 0.233 & 0.223 & 0.223 & 0.230 & 0.005 & 0.927 \\
\hline \multicolumn{7}{|c|}{ Chemical composition of muscle (\%) } \\
\hline $\mathbf{D M}$ & 29.16 & 29.06 & 29.66 & 29.40 & 0.250 & 0.877 \\
\hline $\mathbf{C P}$ & 20.56 & 20.88 & 21.20 & 20.70 & 0.103 & 0.144 \\
\hline $\mathbf{E E}$ & 2.51 & 20.47 & 2.40 & 2.53 & 0.099 & 0.978 \\
\hline $\mathbf{C A}$ & 1.34 & 1.24 & 1.25 & 1.30 & 0.046 & 0.895 \\
\hline
\end{tabular}

${ }^{\mathrm{a}, \mathrm{b}}$ Means in the same row having different litter are significantly different $(\mathrm{P}<0.05)$

The relative weight of heart, bursa, kidney and spleen (g organ /100 g BW) were not significantly affect by humate supplementation, however, the relative liver weight was significant increased by feeding humate $(0.25 \%)$. In an experimental model with partially hepatectomised rats, long-term application of humic acid resulted in the stimulation of omithine decarboxylase, an increase in spermidine and histamine as well as DNA and RNA levels and in overall liver mass (Maslinski et al., 1993). It is also clear that the humate plays a role in the liver function and protects somewhat from disease and/ or disturbances (Lotosh, 1991).

There was no significant effects of feeding different levels of humate on chemical composition of muscle including DM, EE and ash, however CP was numerically increased by feeding humate especially $0.25 \%$ humate.

\section{Digestible nutrients coefficients:}

The digestible nutrients coefficients of the experimental diets are shown in (Table 5). Diets supplemented with humate levels improved the digestibility of most nutrients. Digestibility coefficients of nutrients for chicks fed humate $0.25 \%$ recorded the highest values, while the control group recorded the lowest values. Humate 
stabilize the intestinal flora and thus ensure an improved utilization of nutrients in animal feed. This leads to an increase in live weight of the animal without increasing the amount of feed given to the animal (HuminTech, 2004). 
Table 5. Immune response and digestibility coefficient in local chicks as affected by humates supplementation

\begin{tabular}{ccccccc}
\hline Item & \multicolumn{7}{c}{ Humate Levels (\%) } & \multirow{2}{*}{ SEM } & \multirow{2}{*}{ P-value } \\
\cline { 2 - 5 } & \multicolumn{7}{c}{ 0.1 } & $\mathbf{0 . 2 5}$ & $\mathbf{0 . 4 0}$ & & \\
\hline Primary & $4.15^{\mathrm{b}}$ & $4.26^{\mathrm{b}}$ & $6.35^{\mathrm{a}}$ & $4.21^{\mathrm{b}}$ & 0.286 & 0.0001 \\
Secondary & 6.35 & 6.50 & 6.70 & 6.70 & 0.101 & 0.691 \\
\hline \multicolumn{7}{c}{ Digestibility coefficient (\%) } \\
\hline DM & 79.50 & 79.60 & 80.00 & 79.70 & 0.630 & 0.995 \\
CP & 88.0 & 88.70 & 89.20 & 88.50 & 0.509 & 0.904 \\
EE & 74.60 & 75.10 & 75.80 & 74.90 & 0.970 & 0.984 \\
CF & 23.00 & 23.10 & 23.20 & 23.00 & 0.628 & 1.000 \\
\hline
\end{tabular}

${ }^{\mathrm{a}, \mathrm{b}}$ Means in the same row having different litter are significantly different $(\mathrm{P}<0.05)$

\section{PH Values:}

$\mathrm{pH}$ values of ileal content were lowered as a result of humate supplementation. The maximum reduction in ileal $\mathrm{pH}$ values was recorded for the group of chicks fed $0.4 \%$ dietary humate, where the ileal $\mathrm{pH}$ value decreased from 6.0 to 5.1 (Figure 1). These results agree with Kaya and Tuncer (2009) who found that humate bonding character may have protected acidic kimus against neutralizing effects of pancreatic enzymes and gallic secretions and kept the intestinal content $\mathrm{pH}$ low.

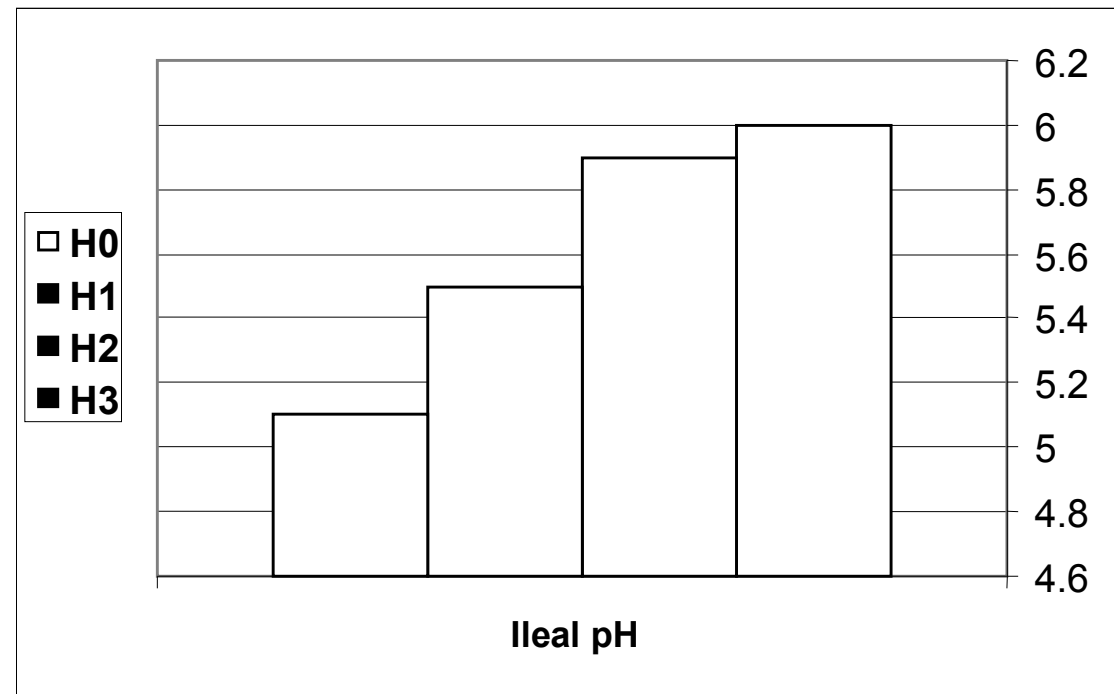

Figure 1. Effect of dietary humate levels on ileal pH values of local chicks

\section{Intestinal Microflora:}

Results concerning the effect of humate on ileal microflora are presented in Figure 2. Microbial total count per gram of ileal content of chicks fed dietary humate levels was obviously less than the control group. Ileum contents of the birds fed diet containing $0.25 \%$ humate had higher counts of Lactobacillus bacteria. However 
feeding diets containing $0.4 \%$ humate resulted in lower count of Lactobacillus bacteria than when feeding $0.25 \%$ humate. It seems that using high level of humate caused sever reduction in ileal; $\mathrm{pH}$ (Figure 1) and produced an unconventional atmosphere for a normal proliferation of Lactobacillus bacteria .This result suggested that, slightly acidic media may enhance the growth of lactobacilli bacteria (Fuller, 1977). Total count of ileal coliforms was inhibited sharply by feeding dietary humate. This sharp reduction was significantly at the levels of 0.2 and $0.4 \%$ humate (Figure 2 ). The mode of action of humate in inhibiting bacterial total count may be due to lowered ileal $\mathrm{pH}$ values of chicks that received dietary humate (Figure 1). Jin et al. (1997) stated that organic acids inhibit the growth of bacteria and their action depends on reducing gut $\mathrm{pH}$ values.

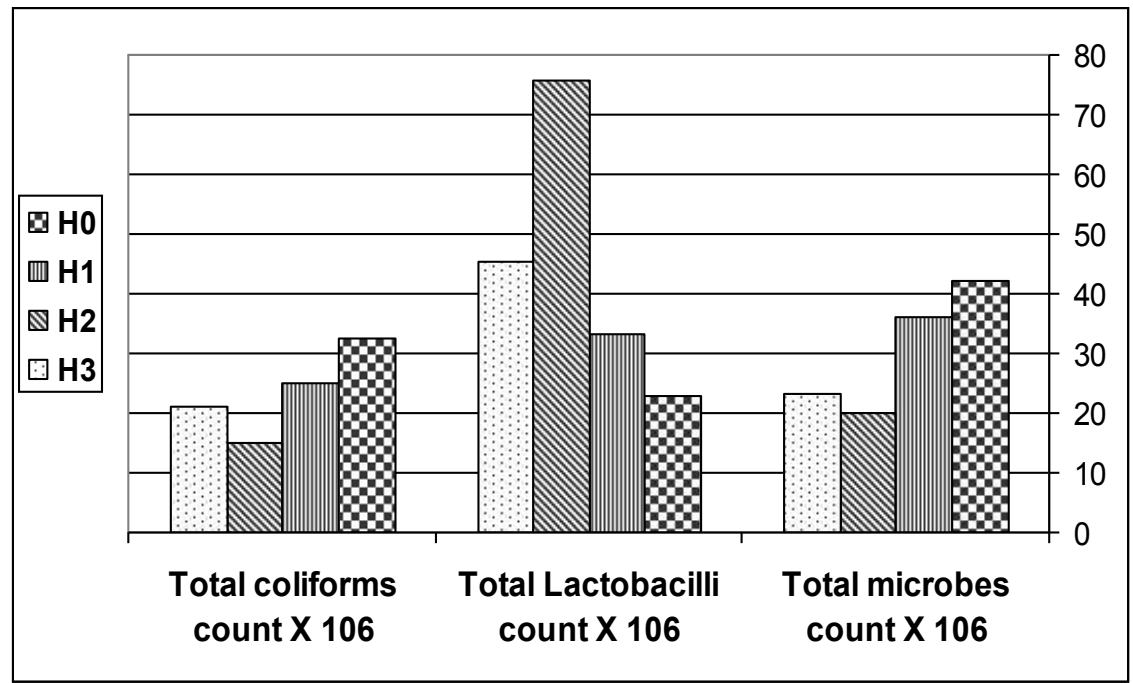

Figure 2. Effect of dietary humate levels on ileal microflora

Fuller (1977) reported that the count of coliforms bacteria decreased as crop pH value reduced. Jin et al. (1997) and Nemcova (1997) stated that intestinal lactobacilli have inhibitory effect against coliforms bacteria. This inhibitory effect may be due to lactobacilli bacteria produce a bacteriocin-like substance (actocidine) which displays inhibitory activity against coliform bacteria. Also, lactobacilli compete with coliform bacteria for sites of adherence on the intestinal surface. Attachment is necessary for proliferation and reducing the rate of removal of organisms due to movement of digesta. The current study supports the observations of (Yoruk et al., 2004 and Avci et al., 2007). It is well established that the gastrointestinal microflora (normal) plays an important role in the health and well being of poultry. Various pathogenic microbes, such as E. coli, have been implicated to reduce the growth of poultry. Possible mechanisms for this reduction of growth are: toxin production, utilization of nutrients essential to the host and suppression of microbes that synthesize vitamins or other host growth factors. 
In soil tested for microbial activity, levels increased 400 to 5000 times with the addition of $300 \mathrm{ppm}$ humate into the soil. Humate added to feed stimulate the microbial growth and the extent can be quite large depending upon the species, the culture medium, and the environment ( Huck et al., 1991). Species for which natural humic substances have been shown to be inhibitory include C. albicans, Ent. Cbacae, Prot. vulgaris, Ps. Aeruginosa, S. typhimurium, St. aureus, St. epidermidis, and St. pyogenes (Riede et al., 1991). It seems that within the body humate stimulate the (good) microbes while suppressing the (bad) microbes. Humic acids are able to reduce the incidence of diarrhoea and other digestive upsets to a considerable extent as well as to improve the animal's defences against pathogens such as E. coli, so humate have antimicrobial properties (Humin Tech, 2004).

\section{Blood Constituents:}

Some blood constituents at the end of the experimental period are shown in Table 4. Supplementation of humate into chicks diets caused a significantly reduction in blood total protein and albumin, $\mathrm{Ca}, \mathrm{Fe}$, and $\mathrm{P}$, however cholesterol, AST and ALT concentrations insignificantly decrease by humate supplementation. Although the decreased values were different than control, they did not reflect any trend that would suggest any toxic effect of humat on muscle, kidney, heart or liver. The blood chemistry results were concordant with relative organ weight results, which showed no dystrophic enlargement or atrophy as it could happen under maladaptive conditions. At 2.5 or $0.40 \%$ level of humate, the reduction in the serum concentrations of $\mathrm{Ca}, \mathrm{Fe}$, and $\mathrm{P}$ may be due to a metal chelating effects of humate, which is affected by large number of carboxylic acid side chains (Klocking, 1994 ).

Table 4. Some blood constituents in local chicks as affected by humates supplementation

\begin{tabular}{|c|c|c|c|c|c|c|}
\hline \multirow[t]{2}{*}{ Item } & \multicolumn{4}{|c|}{ Humate Levels (\%) } & \multirow{2}{*}{ SEM } & \multirow{2}{*}{ P-value } \\
\hline & $\mathbf{0}$ & 0.1 & 0.25 & 0.40 & & \\
\hline \multicolumn{7}{|c|}{ Serum constituents } \\
\hline Total Lipid (g/100ml) & 5.20 & 5.84 & 5.39 & 5.41 & 0.094 & 0.760 \\
\hline Cholesterol (mg/100ml) & 170.0 & 160.0 & 152.0 & 162.0 & 4.557 & 0.643 \\
\hline Total Protein $(\mathrm{g} / \mathbf{1 0 0 \mathrm { ml } )}$ & $4.01^{\mathrm{a}}$ & $3.38^{\mathrm{b}}$ & $3.31^{\mathrm{b}}$ & $3.51^{\mathrm{b}}$ & 0.094 & 0.006 \\
\hline Albumin (g/100ml) & $2.44^{\mathrm{a}}$ & $1.85^{\mathrm{b}}$ & $1.83^{\mathrm{b}}$ & $1.88^{\mathrm{b}}$ & 0.088 & 0.010 \\
\hline Globulin (g/100ml) & 1.57 & 1.53 & 1.48 & 1.62 & 0.033 & 0.530 \\
\hline AST (IU/ L) & 44.5 & 44.3 & 44.0 & 44.43 & 0.122 & 0.536 \\
\hline $\operatorname{ALT}(\mathbf{I U} / \mathbf{L})$ & 9.0 & 8.73 & 8.90 & 9.07 & 0.176 & 0.727 \\
\hline Calcium (mg/dl) & $11.50^{\mathrm{a}}$ & $11.51^{\mathrm{a}}$ & $11.00^{\mathrm{ab}}$ & $10.53^{b}$ & 0.652 & 0.007 \\
\hline Phosphorus(mg/dl) & $6.72^{\mathrm{a}}$ & $6.70^{\mathrm{a}}$ & $6.00^{\mathrm{ab}}$ & $5.85^{\mathrm{b}}$ & 0.381 & 0.065 \\
\hline $\operatorname{Iron}(\mu \mathrm{g} / \mathrm{dl})$ & $21.96^{\mathrm{a}}$ & $21.80^{\mathrm{a}}$ & $20.11^{\mathrm{b}}$ & $20.00^{\mathrm{b}}$ & 1.842 & 0.018 \\
\hline \multicolumn{7}{|c|}{ Hematological } \\
\hline $\mathrm{Hb}(\mathrm{g} / \mathbf{1 0 0 \mathrm { ml } )}$ & $12.67^{\mathrm{b}}$ & $12.90^{\mathrm{b}}$ & $13.20^{\mathrm{a}}$ & $13.00^{\mathrm{b}}$ & 0.146 & 0.013 \\
\hline $\operatorname{RBC}\left(10^{6} \mathrm{Xmm}^{3}\right)$ & $2.12^{\mathrm{b}}$ & $2.17^{\mathrm{b}}$ & $2.36^{\mathrm{a}}$ & $2.26^{\mathrm{ab}}$ & 0.071 & 0.078 \\
\hline WBC $\left(10^{6} \mathrm{Xmm}^{3}\right)$ & 18.72 & 18.55 & 18.81 & 18.76 & 0.059 & 0.520 \\
\hline
\end{tabular}

RBC's and $\mathrm{Hb}$ values were significantly $(\mathrm{P}<0.05)$ increased for chicks fed humate supplementation diet compared with the control group, but WBC's was not affected by dietary treatments (Cetin et al., 2006). Ipek et al.(2008) found that RBC's 
and $\mathrm{Hb}$ were significantly higher in groups fed humic acid compared with control group of Japanese quails, while Rath et al. (2006) and Ipek et al. (2008) showed that humic acid did not have any effect on WBC's in broiler chickens or Japanese quail, respectively.

Lotosh (1991) reported that the RBC's was capable to carry more oxygen in presence of humate. This additional oxygen causes feeling of euphoria, similar to hyperventilating, during the first few days of taking humate.

\section{Immune Response:}

Results presented in Table (5) indicated that the levels of humate significantly affected the primary immunity. The level of 0.25 or $0.1 \%$ humate caused an increase in primary response $(\mathrm{P}<0.05)$ of SRB's of chicks, however, insignificantly influenced either the secondary immune response of SRBC's of chicks. Chicks fed diet containing humate $0.25 \%$ or $0.1 \%$ were significantly recorded the highest antibody titer against SRB's namely 6.35 or 4.26 , respectively. While, chicks fed diets with humate $0.40 \%$ or control groups were significantly recorded the lowest antibody titer against SRBC, being 4.21 or 4.15 , respectively.

Humate boasters the immune system. The mechanism is related to the humate ability to complex sugars with in the body. The abundance of these complex sugars allows the body to manufacture glucoproteins that attach to the killer and $\mathrm{T}$ cell acting as a modulator or communication link between the cells. This regulates the immune system cells and prevents either the $\mathrm{T}$ or killer cells from becoming out of balance (HuminTech, 2004).

\section{Economic Efficiency (EE):}

Results of economic evaluation are summarized in Table 6. It was observed that the $0.25 \%$ humate group had the higher EE by $9 \%$ than that of the control group. This may be due to the improved performance and feed conversion of the treated group. These results are in agreement with El-Husseiny et al. (2008) they reported that chicks fed diets containing humate $0.25 \%$ or humate $0.125 \%$ achieved the best economic efficiency ( $87 \%$ and $92 \%$, respectively) .

Table 6. Economic efficiency of production in local chicks as affected by humates supplementation

\begin{tabular}{lcccc}
\hline Item & \multicolumn{4}{c}{ Humate Levels (\%) } \\
\cline { 2 - 5 } & $\mathbf{0}$ & $\mathbf{0 . 1}$ & $\mathbf{0 . 2 5}$ & $\mathbf{0 . 4 0}$ \\
\hline Average feed intake (g/bird): & 1722.0 & 1706.7 & 1684.0 & 1720.0 \\
$\quad$ Starter diet (0-8wks) & 990.66 & 981.66 & 980.66 & 980.00 \\
$\quad$ Grower diet (8-12wks) & - & 2.69 & 6.66 & 10.89 \\
Humate intake (g) & & & & \\
Feed costs (L.E /bird): & 3.358 & 3.327 & 3.284 & 3.354 \\
$\quad$ Starter diet (0-8wks) & 1.663 & 1.650 & 1.648 & 1.646 \\
$\quad$ Grower diet (8-12wks) & - & 0.040 & 0.100 & 0.163 \\
Humate costs (L.E /bird) & 5.021 & 5.017 & 5.032 & 5.163 \\
Feed + Humate costs (L.E /bird) & 1084.2 & 1107.5 & 1146.8 & 1093.5 \\
Average live weight (g/bird) & 13 & 13 & 13 & 13 \\
Price /kg live weight (L.E)* & 14.095 & 14.397 & 14.908 & 14.215 \\
Total revenue & 9.074 & 9.380 & 9.876 & 9.052 \\
Net revenue & & & & \\
\hline
\end{tabular}




\begin{tabular}{|c|c|c|c|c|}
\hline $\begin{array}{l}\text { Economic efficiency (EE)** } \\
\text { Relative economic efficiency } * * *\end{array}$ & $\begin{array}{c}1.807 \\
100\end{array}$ & $\begin{array}{l}1.870 \\
103\end{array}$ & $\begin{array}{c}1.963 \\
109\end{array}$ & $\begin{array}{c}1.753 \\
103\end{array}$ \\
\hline \multicolumn{5}{|c|}{ *According to the local market price during the experiment at (2009) } \\
\hline \multicolumn{5}{|c|}{ **Net revenue per unit feed cost } \\
\hline \multicolumn{5}{|c|}{$* * *$ Assuming the EE of control diet equals $100 \%$} \\
\hline \multicolumn{5}{|c|}{$\begin{array}{l}\text { Price of } 1 \mathrm{~kg} \text { starter diet }=1.950 \text { L.E, Price of } 1 \mathrm{~kg} \text { grower diet }=1.680 \mathrm{~L} . \mathrm{E} \text {, } \\
\text { Price of } 1 \mathrm{~kg} \text { humate }=15 \mathrm{~L} . \mathrm{E}\end{array}$} \\
\hline CONCLUSION & & & & \\
\hline
\end{tabular}

According to results of this study, it could be concluded that the addition of humate $(0.25 \%)$ to chick diets may improved growth performance, immune response to SRB's and economic efficiency.

\section{REFERENCES}

AOAC, 2000. Official Methods of Analysis. 17 $7^{\text {th }}$ ed. Assoc. off. Anal. Chem., Arlington, VA.

American Public Health Association A.P.H.A., 1985. Standard Methods for the Examination of Water and Waste Water. $16^{\text {th }}$ Ed. APHA, Washington, D. C.

Attia Y.A., R.A. Hassan, M.H. Shehatta and Slawa B. Abd El-Hady, 2005. Growth, carcass quality and serum constituents of slow growing chicks as affected by betaine addition to diets containing a different levels of methionine. International J. of Poultry Science, 4(11): 856-865.

Bachman S.E. and M.M. Mashaly, 1986. Relationship between circulating thyroid hormone and cell mediated immunity in immature male chickens. Develop. Comp. Immunol., 11: 203.

Bachman S.E. and M.M. Mashaly, 1986. Relationship between circulating thyroid hormone and humoral immunity in immature male chickens. Develop. Comp. Immunol., 10: 395.

Bailey C.A., K.E. White and S.L. Donke, 1996. Evaluation of Menefee humate on the performance of broilers. Poult. Sci., 75 (suppl. 1): 84, (Abstr.)

CVMP (Committee for Veterinary Medicinal Products), 1999. Humic acid and their sodium salts (summary report). The European Agency for the Evaluation of Medical Products. EMEA/ MRL/ 554/ 99-FINAL February, 1999.

Cetin N., E. Cetin and B.K. Guclu, 2006. Effect of humate and organic acids supplementation to ration on some haematological parameters in laying hens. Ankara Univ. Vet. Fak. Derg., 53: 165-168.

Duncan D.B. ,1955. Multiple range and multiple F. tests. Biometrics, 11:1-42.

Egyptian Feed Composition Tables for Animal and Poultry Feedstuffs, 2001. Technical bulletin No. 1. Central Lab. for Feed and Food, Ministry of Agric., Egypt.

El-Afifi Sh.F., M. El-Medney and M. Attia, 2001. Effect of citric acid supplementation in broiler diets on performance and intestinal microflora. Egypt. Poult. Sci., 21(II): 491-505.

Eren M., G. Deniz, S.S. Gezen and I.I. Turkmen, 2000. Broyler ymlerine katilan humatlarin besi performansi, serum mineral konsontrasyonu ve kemik kulu uzerine etkileri, Ankara Univ. Vet. Fak. Deg., 47: 255-263. 
Fuller R., 1977. The importance of lactobacilli in maintaining normal microbial balance in the crop. British Poultry Science, 18: 84-94.

Haddading M.S.Y., S.M. Abdulrahim and A.S. Hashlamoum, 1996. Effect of lactobacilli acidophilus on the production and chemical composition of hen's egg. Poult. Sci., 75: 494.

Humin Tech, 2004. Huminfeed- Tierfutterzusatze and Veterinar Medizin and Huminsaure Basierende Produkte. Humintech ${ }^{\circledR}$ Humintech Gmbh, Heerdter Landstr. 189/ D, D-40549 Dusseldorf, Germany, http://www.fulvic.de/049/animalfeeds/products/huminfeed.html.

Ipek H., M. Avci, M. Iriadam, O. Kaplan and N. Denek, 2008. Effects of humic acid on some haematological parameters, total antioxidant capacity and laying performance in Japanese quails. Europ. Poult. Sci., 72: 245-250.

Islam K.M.S., A. Schuhmacher and J.M. Gropp, 2005. Humic acid substances in animal agriculture. Pakistan Journal of Nutrition, 4(3): 126-134.

Izat A.L., N.M. Tedwell, R.A. Thomas, M.E. Reiber, M.H. Adams, M. Colberg and P.W. Waldroup, 1990. Effect of buffered propionic acid in diets on the performance of broiler chickens and on microflora of the intestine and carcass. Poultry Science, 69: 818-826.

Jin L.Z., Y.W. Ho, N. Abdullah and S. Jalaludin, 1997. Probiotics in poultry: modes of action. World's Poul. Sci. Association, 53: 355-368.

Kai O.H., N. Nagase, M. Ishikawa, Kokegawa Suzuki and K. Sato, 1988. Effects propylthiouracial (PTU) on the immunological status of the chickens. Develop. Comp. Immuno., 12: 145.

Karaoglu M., M. Macit, N. Esenbuga, H. Durdage, L. Turgut and C. Bilgin, 2004. Effect of supplemental humate at different levels on the growth performance, slaughter and carcass traits of broilers. International J. of Poult. Sci., 3(6): 406410.

Kaya C.A. and S.D. Tuncer, 2009 . The effect of humates on fattening performance, carcass quality and some blood parameters of broilers . Journal of Animal and Veterinary Advances, 8 (2) : 281 - 284

Klasing K.C. and R.E. Austic, 1984. Changes in protein synthesis due to an inflammatory challenge. Proc. Soc. Exp. Biol. Med., 176: 285-291.

Kocabagli N., M. Alp, N. Acar and R. Kahraman, 2002. The effects of dietary humate supplementation on broiler growth and carcass yield. Poult. Sci., 81: 227230.

Lotosh, T.D., 1991. Experimental bases and prospects for the use of humic acid preparations from peat in medicine and agricultural production. Nauchnye Doki Vyss Shkoly Biol. Nauki., 10: 99-103.

Maslinski C., W.A. Fogel and W. Andrzejewski, 1993. An examination of humate stimulated liver functions. Acta. Pol. Pharm., 50(4-5): 413-416.

National Research Council (N.R.C.). Nutrient requirements of poultry $9^{\text {th }}$ Ed. National Academy Press, Wasshington, DC. 1994.

Nemcova R., 1997. Criteria for selection of lactobacilli for probiotics use. Vet. Med. (Praha), Jan., 42(1): 19-27.

Parks C., P.R. Ferket; L.N. Thomas and J.L. Grimes, 1986. Growth performance and immunity of turkeys fed high and low crude protein diets supplemented with Menefee humate. Poult. Sci., 74: 138-143. 
Parks C.W., 1998. The use of Menefee Humatein typical and low-crude protein diets for turkey toms and in the bioremediation of petroleum-contaminated soil amended with poultry litter as a co-substrate and nutrient source. M. Sc. Thesis, North Carolina State University, Raleigh, N. C.

Pukhova G.G., N.A. Druzhina, L.M. Stepchenko and E.E. Chebotarev, 1987. The influence of natrium humate on animals irradiated with lthal doses. Radiobiologiia, 27: 650-653.

Rath N.C., W.E. Huff and G.R. Huff, 2006. Effects of humic acid on broiler chickens. Poult. Sci., 85: 410-414.

SAS Institute, 1998. SAS/ STAT User's Guide: Statistics Version 6, Cary, NC, SAS Institute.

Seen T.L. and A.R. Kingman, 1973. A review of humus and humic acids. Research Series Report No: 145. South Carolina Agricultural Experiment Station, Clemson, $\mathrm{SC}$.

Shermer C.L., K.G. Maciorowski, C.A. Bailey, F.M. Byers and S. Ricke, 1998. Caecal metabolilites and microbial population in chickens consuming diets containing a mined humate compound. J. Sci. Food Agric., 77: 479-486.

Stevenson F.J., 1994. Humus-chemistry genesis composition, reactions. John Wiley and Sons, New York, NY.

Vogt H., S. Matths and S. Harnsch, 1981. The effect of organic acid in the rations on the performance of broiler and laying hens. Arch. Geflugelkd, 45: 221-232.

Vogt H., S. Matths and S. Harnsch, 1982. The effect of organic acid on the performance of broilers $2^{\text {nd }}$ report. Arch. Geflugelkd, 46: 223-227.

Waldroup A., S. Kaniawty and A. Mauromous Taxos, 1995. Performance characteristics and microbiological aspects of broiler fed diets supplemented with organic acid. J. Food Protection, 58(5): 482-489.

Yamamoto Y. and B. Glick, 1982. A comparison of the immune response between two lines of chickens selected for differences in the weight of the bursa of fabricius. Poult. Sci., 61: 2129.

Yoruk M.A., M. Gul, A. Hayirli and M. Macit, 2004. The effects of supplementation of humate and probiotics on egg production and quality parameters during the late laying period in hens. Poult. Sci., 83: 84-88. 


$$
\begin{aligned}
& \text { تأثير إضافة الهيموتات على الأداء الإنتاجى وميكروبات الأمعاء فى الكتاكيت المحلية }
\end{aligned}
$$

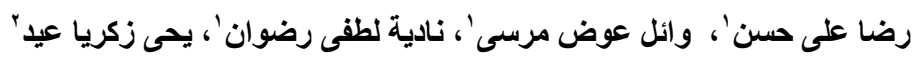

$$
\begin{aligned}
& 1 \text { ـ معهج بحوث الإنتاج الحيوانس، مركز البحوث الزيراعية، وزارة الزراعة، مصر،r ـ قسم إنتاج الدواجن، } \\
& \text { كلية زراعة كفرالشيخ ، جامعة كفرالثيخ }
\end{aligned}
$$

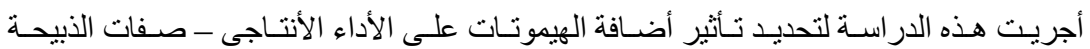

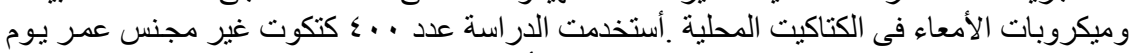

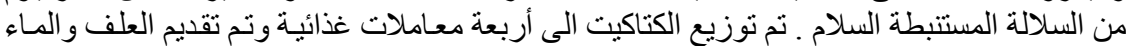

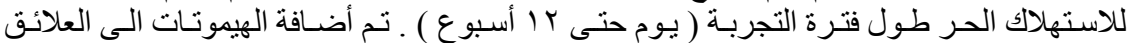

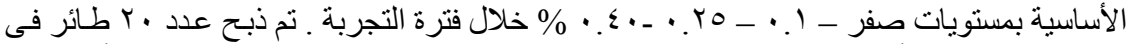

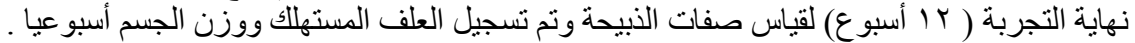

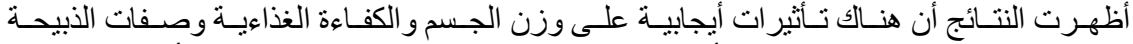

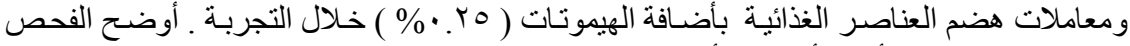

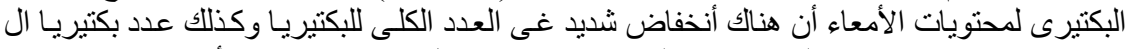

$$
\begin{aligned}
& \text { Coliforms }
\end{aligned}
$$

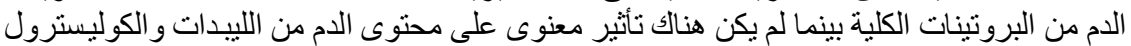

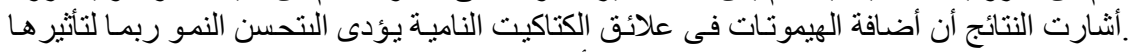

$$
\begin{aligned}
& \text { على التو ازن بين الميكروبات الضارة و النافعة بالأمعاء. }
\end{aligned}
$$

